\title{
ANALISIS EFEKTIVITAS BIAYA PADA PASIEN INFEKSI SALURAN KEMIH (ISK) RAWAT INAP DI RUMAH SAKIT BHAYANGKARA MANADO
}

\author{
Gabrilia P. C. Sukandi' ${ }^{1}$, Gayatri Citraningtyas ${ }^{1)}$, Paulina V. Y. Yamlean') \\ 1)Program Studi Farmasi FMIPA UNSRAT Manado, 95115
}

\begin{abstract}
Urinary tract infections are a clinical condition due to the presence of microorganisms in the urine and the potential for invasion of the upper urinary tract, invading the renal pelvic mucosa and extending into the interstitial tissues of the kidneys. Urinary tract infections treated with antibiotics are one of the significant cost categories in the pharmaceutical budget in hospitals. The purpose of this study was to determine a more cost effective therapy between the use of Ceftriaxone and Ciprofloxacin in UTI patients hospitalized at Bhayangkara Hospital, Manado. This study uses a descriptive research method with retrospective data collection. The sample in this study were 36 patients including 15 patients using Ceftriaxone and 21 patients using Ciprofloxacin. The results showed that the most cost-effective antibiotic was Ceftriaxone with an ACER value of IDR 781,890 and ICER value of IDR 551,255.
\end{abstract}

Keywords: Cost Effectiveness Analysis, Urinary Tract Infections, Ceftriaxone, Ciprofloxacin.

\begin{abstract}
ABSTRAK
Infeksi saluran kemih adalah keadaan klinis akibat adanya mikroorganisme dalam urin dan berpotensi untuk invasi ke saluran kemih bagian atas, menginvasi mukosa pelvis ginjal dan meluas ke dalam jaringan interstisial ginjal. Infeksi saluran kemih diobati dengan antibiotik yang menjadi salah satu kategori biaya yang signifikan dalam anggaran farmasi di rumah sakit. Tujuan penelitian ini untuk menentukan terapi yang lebih cost effective antara penggunaan Seftriakson dan Siprofloksasin pada pasien ISK rawat inap di RS Bhayangkara Manado. Penelitian ini menggunakan metode penelitian deskriptif dengan pengambilan data secara retrospektif. Sampel pada penelitian ini sebanyak 36 pasien diantaranya 15 pasien menggunakan Seftriakson dan 21 pasien menggunakan Siprofloksasin. Hasil penelitian menunjukan, antibiotik yang paling cost-effective adalah Seftriakson dengan nilai ACER sebesar Rp. 781.890 dan nilai ICER sebesar Rp. 551.255.
\end{abstract}

Kata Kunci : Analisis Efektivitas Biaya, Infeksi Saluran Kemih, Seftriakson, Siprofloksasin. 


\section{PENDAHULUAN}

Penyakit infeksi merupakan penyebab paling utama tingginya angka kesakitan (morbiditas) dan angka kematian (mortalitas) terutama pada negara-negara berkembang seperti halnya Indonesia (Darmadi, 2008). ISK dapat menyerang segala usia dari bayi hingga lansia baik perempuan maupun laki-laki (Purnomo, 2014). Infeksi saluran kemih diobati dengan antibiotik. Standarisasi pengobatan mempertimbangkan obat yang lebih efektif dengan biaya murah untuk mengurangi angka kesakitan dan biaya kesehatan. (Pratiwi, 2015).

Berdasarkan survei di RS Bhayangkara Manado, antibiotik yang digunakan untuk pemakaian ISK ialah Seftriakson dan Siprofloksasin. Adanya pasien yang menjalani terapi yang berbeda dengan diagnosis yang sama menjadi dasar dilakukannya penelitian ini bagaimana perbandingan efektivitas biaya khususnya penggunaan antibiotik Seftriakson dan Siprofloksasin terhadap pasien infeksi saluran kemih di RS Bhayangkara.

Kajian farmakoekonomi dilakukan untuk mengidentifikasi obat yang menawarkan efektivitas lebih tinggi dengan harga lebih rendah sehingga secara signifikan memberikan efektivitas-biaya yang tinggi dan dapat dijadikan rekomendasi pilihan terapi. Cara komprehensif untuk menentukan pengaruh ekonomi dari alternatif terapi obat atau intervensi kesehatan lain yaitu dengan analisis farmakoekonomi yang berupa cost effectiveness analysis (CEA) atau analisis efektivitas biaya (Andayani, 2013).

\section{METODOLOGI PENELITIAN}

\section{Tempat dan Waktu Penelitian}

Penelitian ini dilakukan di Rumah

Sakit Bhayangkara Manado pada bulan

Desember 2018 - Maret 2019.

\section{Jenis dan Rancangan Penelitian}

Jenis dan rancangan penelitian yang digunakan ialah penelitian deskriptif dengan pengambilan data secara retrospektif yang membandingkan direct medical cost (biaya medis langsung) dari obat Seftriakson atau Siprofloksasin pada pasien ISK rawat inap di RS Bhayangkara.

\section{Populasi dan Sampel}

Populasi dalam penelitian ini ialah seluruh pasien ISK rawat inap yang menggunakan obat Seftriakson atau Siprofloksasin di RS Bhayangkara. Sampel dalam penelitian ini yaitu pasien rawat inap dengan diagnosis ISK di RS Bhayangkara periode Januari-Desember 2018. Sampel harus memenuhi kriteria inklusi dan eksklusi, sebagai berikut :

1. Kriteria inklusi

1) Pasien dengan diagnosis ISK yang mendapatkan terapi antibiotik Seftriakson atau Siprofloksasin.

2) Pasien ISK yang dirawat inap usia $\geq$ 18 tahun.

3) Pasien ISK yang memiliki data lengkap.

2. Kriteria eksklusi

1) Pasien ISK dengan penyakit penyerta.

2) Pasien ISK yang diberikan antibiotika kombinasi. 


\section{Analisis Data}

Data dianalisis secara deskriptif dan diuraikan dalam bentuk tabel. Setelah data terkumpul, dilakukan perhitungan biaya medik langsung pada tiap pasien. Data ini digunakan untuk ACER dengan rumus sebagai berikut :

$$
A C E R=\frac{\text { Biaya }}{\text { Efektivitas }}
$$

Keterangan:

$\begin{array}{ll}\text { Biaya } & \text { :Rata-rata biaya terapi } \\ \text { Efektivitas } & \text { :Rata-rata outcome terapi } \\ \text { obat } & \end{array}$

Hasil dari $C E A$ dapat disimpulkan dengan ICER seperti rumus dibawah ini:

ICER $=\frac{\Delta \text { Biaya }}{\Delta \text { Efektivitas }}=\frac{\text { Biaya } A-\text { Biaya } B}{\text { Efektivitas } A-\text { Efektivitas } B}$

Keterangan :

Biaya A : Biaya teknologi baru

Biaya B : Biaya Pembanding

Efektivitas A : Efektivitas teknologi baru

Efektivitas B : Efektivitas Pembanding

\section{HASIL DAN PEMBAHASAN}

Tabel 1. Karakteristik Usia Pasien ISK rawat inap di RS Bhayangkara Manado periode JanuariDesember 2018

\begin{tabular}{ccc}
\hline Umur & $\begin{array}{c}\text { Jumlah Pasien } \\
(\mathbf{n})\end{array}$ & $\begin{array}{c}\text { Persentase } \\
(\mathbf{\%})\end{array}$ \\
\hline $18-25$ & 3 & $8,33 \%$ \\
\hline $26-35$ & 4 & $11,11 \%$ \\
\hline $36-45$ & 4 & $11,11 \%$ \\
\hline $46-55$ & 10 & $27,78 \%$ \\
\hline $45-65$ & 15 & $41,67 \%$ \\
\hline Total & $\mathbf{3 6}$ & $\mathbf{1 0 0}$ \\
\hline
\end{tabular}

Tabel 1 menunjukkan pasien ISK yang berumur 18-25 tahun sebanyak 3

pasien $(8,33 \%)$, umur 26-35 tahun sebanyak 4 pasien $(11,11 \%)$, umur 36-45 tahun sebanyak 4 pasien $(11,11 \%)$, umur 46-55 tahun sebanyak 10 pasien $(27,78 \%)$ dan umur 56-65 tahun sebanyak 15 pasien $(41,67 \%)$.

Dalam penelitian ini ditemukan bahwa pasien dengan kelompok usia 36 sampai 65 tahun lebih beresiko mengalami penyakit Infeksi Saluran Kemih disebabkan pada usia tersebut terjadi penurunan daya imun atau meningkatnya kerentanan terhadap infeksi (Kasmed, 2007). Angka kejadian ISK meningkat seiring bertambahnya usia. ISK sering muncul pada orang-orang yang lebih tua baik dalam

komunitas dan dalam perawatan jangka panjang. Sejumlah faktor predisposisi yang mengakibatkan ISK pada orang-orang yang lebih tua, antara lain penyakit prostat pada pria. Pada wanita, defisiensi estrogen postmenopause sering dikaitkan dengan rekurensi ISK (Beveridge, 2011).

Tabel 2. Karakteristik Jenis Kelamin Pasien ISK rawat inap di RS Bhayangkara Manado periode Januari-Desember 2018

\begin{tabular}{ccc}
\hline Jenis Kelamin & $\begin{array}{c}\text { Jumlah } \\
\text { Pasien }\end{array}$ & $\begin{array}{c}\text { Presentase } \\
(\mathbf{\%})\end{array}$ \\
Laki-laki & 9 & $25 \%$ \\
Perempuan & 27 & $75 \%$ \\
\hline Total & $\mathbf{3 6}$ & $\mathbf{1 0 0}$
\end{tabular}

Tabel 2 menunjukkan pasien ISK dengan jenis kelamin laki-laki sebanyak 9 pasien $(25 \%)$ dan pada perempuan sebanyak 
27 pasien $(75 \%)$. 
Wanita cenderung lebih sering menderita ISK dibandingkan pria karena bakteri dapat menjangkau kandung kemih dengan lebih mudah pada wanita dibandingkan dengan pria. Panjang uretra pada wanita lebih pendek (sekitar 3-5 cm) daripada uretra pria (sekitar $15-18 \mathrm{~cm}$ ), sehingga bakteri yang akan menyerang mempunyai jarak yang lebih pendek dan dekat untuk menginfeksi bagian saluran kemih (Sukandar, 2009)

\section{Analisis Efektivitas Biaya}

Tabel 3. Biaya Medik Langsung (direct medical cost) pasien ISK rawat inap menggunakan terapi antibiotik Seftriakson di RS Bhayangkara Manado periode Januari-Desember 2018

\section{Komponen Biaya}

\begin{tabular}{cccccc}
\cline { 3 - 5 } No & Pasien & $\begin{array}{c}\text { Biaya } \\
\text { Perawatan }(\mathbf{R p})\end{array}$ & $\begin{array}{c}\text { Biaya } \\
\text { Pengobatan }(\mathbf{R p})\end{array}$ & $\begin{array}{c}\text { Biaya Uji } \\
\text { Laboratorium }(\mathbf{R p})\end{array}$ & Total Biaya (Rp) \\
\hline 1. & AK & 4.145 .000 & 199.440 & 280.000 & 4.624 .440 \\
\hline 2. & AM & 2.739 .000 & 176.740 & 280.000 & 3.195 .740 \\
\hline 3. & AP & 3.442 .000 & 180.500 & 280.000 & 3.902 .500 \\
\hline 4. & AT & 2.739 .000 & 180.920 & 280.000 & 3.199 .920 \\
\hline 5. & DK & 4.145 .000 & 198.080 & 280.000 & 4.623 .080 \\
\hline 6. & FN & 3.442 .000 & 182.600 & 280.000 & 3.904 .600 \\
\hline 7. & LR & 3.442 .000 & 182.600 & 280.000 & 3.904 .600 \\
\hline 8. & MT & 2.739 .000 & 173.380 & 280.000 & 3.192 .380 \\
\hline 9. & MT & 4.848 .000 & 207.720 & 280.000 & 5.335 .720 \\
\hline 10. & MT & 4.145 .000 & 197.640 & 280.000 & 4.622 .640 \\
\hline 11. & MW & 4.145 .000 & 204.840 & 280.000 & 4.629 .840 \\
\hline 12. & OT & 2.036 .000 & 168.740 & 280.000 & 2.484 .740 \\
\hline 13. & RW & 3.442 .000 & 191.020 & 280.000 & 3.913 .020 \\
\hline 14. & SM & 2.036 .000 & 166.660 & 280.000 & 2.482 .660 \\
\hline 15. & WE & 4.848 .000 & 201.620 & 280.000 & 5.329 .620 \\
\hline
\end{tabular}

Total direct medical cost

Rp. 59.345.500

Direct medical cost per pasien

Rp. 3.956.366

Tabel 3 menunjukkan total biaya medik langsung dengan biaya terkecil yaitu Rp. 2.482.660 dan total biaya medik terbesar yaitu Rp. 5.335.720. Perbedaan biaya medik langsung dari masing-masing pasien dikarenakan lamanya pasien di rawat inap di rumah sakit, karena semakin lama pasien dirawat maka semakin besar juga biaya yang harus dikeluarkan pasien. Total direct medical cost yang dikeluarkan pasien untuk mendapatkan pelayanan kesehatan dengan menggunakan antibiotik seftriakson untuk ke-15 pasien yaitu sebesar Rp. 59.345.500 dengan direct medical cost per pasien $\mathrm{Rp}$. 3.956.366. 


\section{Perhitungan Biaya Medik Langsung menggunakan Siprofloksasin}

Tabel 4. Biaya Medik Langsung (direct medical cost) pasien infeksi saluran kemih rawat inap menggunakan terapi antibiotik Siprofloksasin di RS Bhayangkara Manado periode Januari-Desember 2018

\begin{tabular}{cccccc}
\hline No & Pasien & $\begin{array}{c}\text { Biaya } \\
\text { Perawatan (Rp) }\end{array}$ & $\begin{array}{c}\text { Komponen Biaya } \\
\text { Pengobatan }(\mathbf{R p})\end{array}$ & $\begin{array}{c}\text { Biaya Uji } \\
\text { Laboratorium (Rp) }\end{array}$ & Total Biaya (Rp) \\
\cline { 3 - 5 } 1. & AA & 5.551 .000 & 432.587 & 280.000 & 6.263 .587 \\
\hline 2. & AM & 2.739 .000 & 242.786 & 280.000 & 3.261 .786 \\
\hline 3. & AM & 4.145 .000 & 349.658 & 280.000 & 4.774 .658 \\
\hline 4. & CL & 2.036 .000 & 177.040 & 280.000 & 2.493 .040 \\
\hline 5. & CT & 2.036 .000 & 184.580 & 280.000 & 2.500 .580 \\
\hline 6. & EL & 2.036 .000 & 177.040 & 280.000 & 2.493 .040 \\
\hline 7. & HS & 2.739 .000 & 242.786 & 280.000 & 3.261 .786 \\
\hline 8. & HT & 2.036 .000 & 177.040 & 280.000 & 2.493 .040 \\
\hline 9. & JP & 3.442 .000 & 292.672 & 280.000 & 4.014 .672 \\
\hline 10. & JP & 4.848 .000 & 383.921 & 280.000 & 5.511 .921 \\
\hline 11. & LS & 3.442 .000 & 291.727 & 280.000 & 4.013 .727 \\
\hline 12. & MM & 4.848 .000 & 407.764 & 280.000 & 5.535 .764 \\
\hline 13. & MS & 2.036 .000 & 174.960 & 280.000 & 2.490 .960 \\
\hline 14. & NK & 2.739 .000 & 232.386 & 280.000 & 3.251 .386 \\
\hline 15. & SD & 2.739 .000 & 232.386 & 280.000 & 3.251 .386 \\
\hline 16. & SH & 2.739 .000 & 242.786 & 280.000 & 3.261 .786 \\
\hline 17 & SP & 2.036 .000 & 182.500 & 280.000 & 2.498 .500 \\
\hline 18. & TM & 2.036 .000 & 177.040 & 280.000 & 2.493 .040 \\
\hline 19. & TPS & 2.036 .000 & 182.500 & 280.000 & 2.498 .500 \\
\hline 20. & VPW & 4.145 .000 & 349.998 & 280.000 & 4.774 .998 \\
\hline 21. & YS & 5.551 .000 & 442.127 & 280.000 & 6.273 .127 \\
\hline
\end{tabular}

Total direct medical cost Rp. 77.411.284

Direct medical cost per pasien $\quad$ Rp. 3.686.251

Tabel 4 menunjukkan total biaya medik langsung dengan biaya terkecil yaitu Rp 2.490.960 dan total biaya medik terbesar yaitu Rp 6.273.127. Perbedaan biaya medik langsung dari masing-masing pasien dikarenakan lamanya pasien di rawat inap di rumah sakit, karena semakin lama pasien dirawat maka semakin besar juga biaya yang harus dikeluarkan pasien. Total direct medical cost yang dikeluarkan pasien untuk mendapatkan pelayanan kesehatan dengan menggunakan antibiotik seftriakson untuk ke-21 pasien yaitu sebesar Rp 77.411.284 dengan direct medical cost per pasien $\mathrm{Rp}$ 3.686.251. 


\section{Perhitungan Efektivitas Biaya Berdasarkan ACER}

Tabel 5. Perhitungan ACER penggunaan Seftriakson dan Siprofloksasin pasien infeksi saluran kemih di RS Bhayangkara periode Januari - Desember 2018

\begin{tabular}{|c|c|}
\hline $\begin{array}{c}\text { Rata-rata direct } \\
\text { medical cost }(\mathrm{C})(\mathrm{Rp})\end{array}$ & $\begin{array}{c}\text { Rata-rata lama hari } \\
\text { rawat inap } \\
\text { (Efektivitas/E) (Hari) }\end{array}$ \\
\hline Seftriakson & 781.890 \\
\hline Siprofloksasin & 806.619 \\
\hline $\begin{array}{l}\text { Tabel } 5 \text { menunjukkan hasil dari } \\
\text { perhitungan direct medical cost per pasien } \\
\text { yang dibagi rata-rata lama hari rawat inap. } \\
\text { ACER Seftriakson yang didapat yaitu Rp. } \\
\text { 781.890/hari } \quad \text { sedangkan } \\
\text { Siprofloksasin yang didapat sebesar Rp. } \\
\text { 806.619/hari. Maksud dari angka-angka }\end{array}$ & $\begin{array}{l}\text { dalam ACER adalah setiap peningkatan } \\
\text { outcome dibutuhkan biaya sebesar } A C E R \\
\text { (Lorensia, 2016). Semakin kecil nilai } A C E R \\
\text { maka obat tersebut semakin cost-effective. } \\
\text { Dilihat dari nilai ACER Seftriakson yang } \\
\text { lebih kecil dari nilai ACER Siprofloksasin, } \\
\text { dapat diartikan bahwa Seftriakson lebih } \\
\text { cost-effective dibandingkan Siprofloksasin. }\end{array}$ \\
\hline
\end{tabular}

\section{Perhitungan Efektivitas Biaya Berdasarkan ICER}

Tabel 6. Hasil Perhitungan ICER antibiotik Seftriakson dan Siprofloksasin untuk pasien infeksi saluran kemih di RS Bhayangkara Manado.

\begin{tabular}{ccc}
\hline$\square \square$ & $\square \square$ & ICER $(\square \square / \square \square)$ \\
\hline $\begin{array}{c}3.686 .251-3.956 .366= \\
-270.115\end{array}$ & $4.57-5.06=-0.49$ & $-270115 /-0.49=551.255$ \\
\hline
\end{tabular}

Tabel 6 menunjukkan nilai ICER

yaitu Rp. 551.255/hari. Nilai ICER yang

diperoleh merupakan besarnya biaya tambahan untuk memperoleh 1 hari pengurangan lama rawat inap pada pasien infeksi saluran kemih jika akan dilakukan perpindahan dari Seftriakson ke Siprofloksasin.

\section{KESIMPULAN}

Dari hasil penelitian dapat disimpulkan bahwa terapi yang lebih costeffective antara penggunan antibiotik Seftriakson dan Siprofloksasin pada pengobatan infeksi saluran kemih di RS 
pemberian antibiotik Seftriakson. Hal ini dapat dilihat dari nilai ACER Seftriakson sebesar Rp. 781.890/hari dan nilai ICER sebesar Rp. 551.255/hari

\section{SARAN}

Penelitian selanjutnya diharapkan dapat melakukan penelitian secara prospektif dengan melihat keadaan pasien selama dirawat di Rumah Sakit Bhayangkara Manado.

\section{DAFTAR PUSTAKA}

Andayani, Tri Murti, 2013.

Farmakoekonomi Prinsip dan

Metodologi, Bursa Ilmu,

Yogyakarta. 
Beveridge L, Davey PG, Phillips G, McMurdo MET. 2011. Optimal management of urinary tract infection in older people. Dovepress Journal. 6 :173-179.

Darmadi. 2008. Infeksi Nosokomial : Problematika dan Pengendaliannya. Salemba Medika, Jakarta.

Kasmed. 2007. Hubungan Antara Kualitas Perawatan Kateter dengan Kejadian Infeksi Nosokomial Saluran Kemih. Universitas Diponegoro, Semarang

Lorensia, A., dan Doddy, D.Q. 2016. Farmakoekonomi Edisi Kedua. UBAYA, Surabaya.

Pratiwi, Hening, Septimawanto D. P. 2015. Evaluasi Peresepan Antibiotik Pasien Infeksi Saluran Kemih di Instalasi Rawat Inap Rumah Sakit Roemani Semarang. Acta Pharmaciae Indonesia. 85-91.

Purnomo, B. 2014. Dasar-Dasar Urologi Edisi 2. Sagung Seto, Jakarta.

Sukandar, E. Y. 2009. ISO Farmakoterapi. PT. ISFI Penerbitan, Jakarta. 